meningitis and one of septicaemia in man caused by haemolytic streptococci. Further strains have been isolated from man by several workers, and Kloppenburg et $\mathrm{al}^{4}$ drew attention to the fact that all 15 reported cases had occurred in the Netherlands or Denmark and nearly all were of purulent meningitis. One patient kept pigs on his own premises for future processing in the factory, and the actual source of his infection was not identified. The incubation period, however, indicated that infection had resulted from his injury. Swabs from the machine and other apparatus at the factory were unobtainable and swabs from the patient's hand wound taken the day after admission failed to grow streptococci. Most previous cases have resulted from an infected wound. Purulent arthritis is a well known complication of group $\mathbf{R}$ streptococcal infection in pigs but as yet has not been recorded in man. Unfortunately our patient's hip was aspirated too late in the course of his illness to isolate the infecting organism, which was presumably a streptococcus.

We thank the staff of the Public Health Laboratory, Gloucester, for the initial investigations, the staff of the Cross-infection Reference Laboratory, Central Public Health Laboratory, Colindale, London, for specialist advice, and $\operatorname{Dr} R$ F Jarrett for permission to report this case. The case reported here is referred to by Windsor and Elliott ${ }^{5}$ in a footnote to their paper on streptococcal infection in young pigs.

${ }^{1}$ Field, H I, Buntain, D, and Dove, J T, Veterinary Record, 1954, 66, 453.

2 de Moor, C E, Verslagen en Medelingen Betreffende de Volksgezondheid, 1959, 2, 474.

3 Perch, B, Kristjansen, P, and Skadhauge, Kn, Acta Pathologica et Microbiologica Scandinavica, 1968, 74, 69.

${ }^{4}$ Kloppenburg, M, Mulder, N H, and Houwerzijl, J, Lancet, 1975, 2, 1218.

5 Windsor, R S, and Elliott, S D, fournal of Hygiene, 1975, 75, 69.

\section{Low molecular weight dextran: a continuing cause of acute renal failure}

Low molecular weight dextran (LMWD), though not usually considered to be highly nephrotoxic, may precipitate acute renal failure (ARF) in certain conditions.' It may be the commonest cause of druginduced ARF. Seven out of eight cases of drug-induced ARF referred to this unit from several hospitals during a recent eight-month period were caused by LMWD (10" ", dextran 40 in six cases and 6", dextran 70 in one case). All seven patients had ischaemic disorders.

\section{Case histories}

The case histories of patients are summarised in the table. In none could any cause other than LMWD be found for the ARF. All had widespread arterial disease and possibly such patients are particularly sensitive to the nephrotoxic effects of LMWD. In every case the onset of renal failure was relatively slow with a progressive decline in urire volume over three to six days. This was well illustrated by case 2 , whose sequential daily urine volumes from the start of LMWD treatment were (in ml) 1900, 1000, 800, $650,155,0$. Circulatory overload developed during this period.

Despite the decline in urine output LMWD was not withdrawn from any of the patients, and five developed complete anuria. During recovery there was not, as in many cases of ARF, a rapid diuresis but a slow rise in urine volume of $100-300 \mathrm{ml} / \mathrm{day}$. Only two patients ( 3 and 6 ) achieved a diuresis of greater than $21 /$ day. Dextran did not help the primary condition of any of the patients.

\section{Comment}

Dextrans of molecular weights below 60000 easily filter through the glomerulus. They may accumulate in proximal tubular cells giving the swollen, vacuolated appearance of "osmotic nephropathy," although this appearance does not correlate with changes in renal function." The high viscosity of concentrated dextran probably causes renal dysfunction by tubular plugging. ${ }^{34}$ Damage is more likely to occur when renal perfusion is reduced ${ }^{4}$-a probable factor in cases 2,4 , and 7 -or if renal damage is already present, ${ }^{1}$ as in patients 2 and 6. Maintenance of diuresis with fluids and diuretics may protect the kidneys ${ }^{3}$ and may have prevented the need for dialysis in cases 4 and 6, who were referred and treated before anuria occurred.

Except in cases 1 and 5 the total dosage of LMWD was within the accepted therapeutic range, but treatment was continued despite falling urine volumes. The occurrence of anuria with $6^{\circ}{ }_{11}$ dextran 70 in patient 7 is unusual, as only a small proportion of the dextrans in this solution are filtered through the glomerulus.

The uses of LMWD are limited. When it is indicated its propensity to cause ARF should be remembered and the following therapeutic rules observed ${ }^{5}$ : (1) do not infuse faster than $11 /$ day; (2) do not give if the urine output is below $1500 \mathrm{ml} /$ day; (3) withdraw if the specific gravity of the urine rises above 1045 ; (4) do not give if the blood urea is above $10 \mathrm{mmol} / 1(60 \mathrm{mg} / 100 \mathrm{ml})$. A reduced urine output indicates that LMWD should be withdrawn and diuresis induced with diuretics and a high fluid intake.

Strict adherence to these rules would probably have prevented all the cases of LMWD-induced renal failure reported here.

${ }^{1}$ Matheson, N A, and Diomi, P, Surgery, Gynuecology and Obstetrics, 1970, 131, 661 .

2 Diomi, P, et al, Laboratory Investigation, 1970, 22, 355.

${ }^{3}$ Mailloux, L, et al, New England fournal of Medicine, 1967, 277, 1113.

${ }^{4}$ Chinitz, J L, et al, Journal of Laboratory and Clinical Medicine, 1971, 77, 76.

${ }^{5}$ Holti, G, Bibliotheca Anatomica, 1973, 11, 359

Department of Medicine, Royal Victoria Infirmary, Newcastle upon Tyne NE1 4LP

T G FEEST, MB, MRCP, senior registrar in nephrology

Case histories of seven patients with acute renal failure after administration of low molecular weight dextran

\begin{tabular}{|c|c|c|c|c|c|c|c|c|c|c|}
\hline $\begin{array}{l}\text { Case } \\
\text { No }\end{array}$ & Age & Sex & Primary diagnosis & $\begin{array}{l}\text { Dose of } 10 \% \\
\text { dextran } 40\end{array}$ & $\begin{array}{l}\text { Initial plasma } \\
\text { urea } \\
\text { concentration } \\
(\mathrm{mmol} / \mathrm{l})\end{array}$ & $\begin{array}{l}\text { Initial urine } \\
\text { volume } \\
\text { (ml/day) }\end{array}$ & $\begin{array}{c}\text { Duration } \\
\text { of } \\
\text { decline }\end{array}$ & $\begin{array}{c}\text { Duration of } \\
\text { complete } \\
\text { anuria }\end{array}$ & $\begin{array}{r}\text { Type and } \\
\text { duration of } \\
\text { dialysis }\end{array}$ & Comment \\
\hline 1 & 72 & $\mathrm{~F}$ & $\begin{array}{l}\text { Diabetic gangrene of } \\
\text { left foot }\end{array}$ & 41 in 2 days & Not measured & Not measured & 3 days & 28 days & $\begin{array}{l}\text { Peritoneal; } \\
4 \text { weeks }\end{array}$ & Leg amputated after ARF \\
\hline 2 & 54 & $\mathbf{F}$ & $\begin{array}{l}\text { Ischaemic left leg, } \\
\text { mesenteric ischaemia }\end{array}$ & 3.51 in 3 days & $17 \cdot 5$ & 1900 & 6 days & 11 days & $\begin{array}{l}\text { 4 weeks } \\
\text { Peritoneal; } \\
15 \text { days }\end{array}$ & $\begin{array}{l}\text { Chronic pyelonephritis. } \\
\text { Leg recovered }\end{array}$ \\
\hline 3 & 86 & $\mathbf{F}$ & Ischaemic right foot & 51 in 5 days & 8 & Not measured & 6 days & 3 days & $\begin{array}{l}\text { Peritoneal; } \\
6 \text { days }\end{array}$ & $\begin{array}{l}\text { Foot improved after } \\
\text { phenol sympathetic } \\
\text { block }\end{array}$ \\
\hline 4 & 78 & $\mathrm{~F}$ & Left brachial embolus & 21 in 2 days & $7 \cdot 5$ & 1000 & 3 days & $12 \mathrm{hrs}$ & Not needed & $\begin{array}{l}\text { Embolectomy under local } \\
\text { analgesia. Early treat- } \\
\text { ment with frusemide }\end{array}$ \\
\hline 5 & 57 & $\mathbf{M}$ & Left popliteal embolus & 61 in 5 days & Not measured & Not measured & 6 days & 14 days & $\begin{array}{l}\text { Peritoneal and } \\
\text { haemodialysis }\end{array}$ & $\begin{array}{l}\text { Leg amputated after ARF. } \\
\text { Died of pneumonia and } \\
\text { disseminated intra- }\end{array}$ \\
\hline 6 & 73 & $\mathbf{M}$ & $\begin{array}{l}\text { Diabetic gangrene of } \\
\text { left foot }\end{array}$ & 5.51 in 5 days & $21 \cdot 9$ & 1500 & 6 days & $=450 \mathrm{ml} /$ day & Not needed & $\begin{array}{l}\text { vascular coagulation } \\
\text { Amputation after renal } \\
\text { recovery. Early } \\
\text { frusemide treatment }\end{array}$ \\
\hline 7 & 70 & $\mathbf{M}$ & $\begin{array}{l}\text { Polycythaemia. } \\
\text { Ischaemic left foot }\end{array}$ & 51 in 5 days* & Not measured & Not measured & 5 days & 6 days & $\begin{array}{l}\text { Haemodialysis; } \\
7 \text { days }\end{array}$ & Some recovery of foot \\
\hline
\end{tabular}

${ }^{*}$ Dose refers to $6 \%$ dextran $70 . \mathrm{ARF}=$ acute renal failure. Conversion: $S I$ to traditional units-plasma urea: $1 \mathrm{mmol} / 1 \approx 6 \mathrm{mg} / 100 \mathrm{ml}$ 